Archive for

Organic Chemistry

Arkivoc 2018, part iv, 13-22

\title{
Synthesis and characterization of dimeric steroids based on 5-oxo-4,5-seco-yne units linked by a diyne spacer
}

\author{
Ricardo M. Valdez-García, ${ }^{a}$ Carlos Alarcón-Manjarrez, ${ }^{a}$ Rafael Arcos-Ramos, ${ }^{\text {b }}$ \\ Marcos Flores-Álamo, ${ }^{a}$ and Martín A. Iglesias-Arteaga*a \\ a Facultad de Química, Universidad Nacional Autónoma de México, \\ Ciudad Universitaria, 04510 México, D.F., México \\ ${ }^{b}$ Departamento de Química de Radiaciones y Radioquímica, Instituto de Ciencias Nucleares, \\ Universidad Nacional Autónoma de México, 04510 México D.F., México \\ Email: martin.iglesias@unam.mx
}

Dedicated to Professor Gordon W. Gribble on the occasion of his retirement from Dartmouth College

Received 12-29-2017

Accepted 01-21-2018

Published on line 02-04-2018

\section{Abstract}

New dimeric steroids in which two 5-oxo-4,5-seco-3-yne steroids units are linked by a flexible diyne spacer, were prepared by both Eglinton and Pd-catalyzed coupling of the corresponding monomers. X-Ray crystallography shows that one of the obtained dimers displays a novel supramolecular network in which the facial hydrophobicity of the steroidal skeleton plays an important role. The crystal packing is dominated by interactions that accommodate the steroid cores in a highly crowded packed columnar self-assembly. Unambiguous NMR characterization of the obtained compounds is also provided.

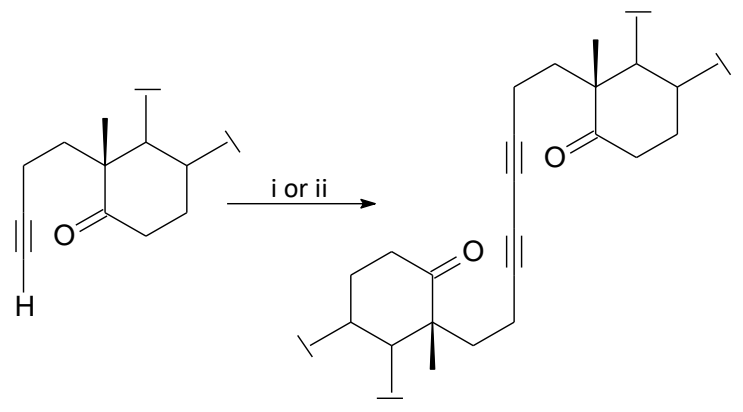

i) Method A $\mathrm{Cu}\left(\mathrm{CH}_{3} \mathrm{COO}\right)_{2} \bullet \mathrm{H}_{2} \mathrm{O} / \mathrm{pyr} / \mathrm{CH}_{3} \mathrm{OH}$ reflux

ii) Method B $\mathrm{Pd}\left(\mathrm{PPh}_{3}\right)_{4}, \mathrm{O}_{2}, \mathrm{Cul} \mathrm{Et}_{3} \mathrm{~N}, \mathrm{RT}$

Keywords: 5-Oxo-4,5-seco-3-yne steroids, Eglinton alkyne coupling, palladium catalyzed alkyne coupling, bis4,4-(5-oxo-4,5-seco-3-yne steroids), NMR, X-ray diffraction 


\section{Introduction}

Steroids are a family of lipophilic compounds that are widespread in nature. Their intrinsic biological activity has kept this kind of compound in the focus of attention for more than a century. The subfamily of steroid dimers added its first members when a few compounds were isolated from nature ${ }^{1}$ or occurred as by-products of various reactions. ${ }^{2}$ The interesting chemical, biological and physical properties of the rising number of steroid dimers isolated from living organisms or obtained by synthesis ${ }^{3-7}$ has prompted intensive activity in this developing field.

Although dimeric steroids are known to form well-defined crystals, reports on the crystal structure of this type of compound are rather scarce, compared to those of monomeric steroids. As part of a program on the development of steroid-based crystalline systems, we have become interested in the preparation of compounds with flexible structural arrangements. In a previous publication we described the synthesis of dimeric terephthalates derived from epimeric 4,5-seco-cholest-3-yn-5-ols that display novel supramolecular networks in the solid state in which the facial hydrophobicity of the steroidal skeletons plays an important role. ${ }^{8}$ This prompted us to set up procedures to prepare dimeric steroids in which the steroid cores are joined by a diyne moiety that acts as a flexible spacer.

1,3-Diynes are considered important building blocks for organic synthesis and material science. This has prompted the development of a large collection of synthetic methods for the preparation of such compounds. ${ }^{10,11}$ In particular, the synthesis of symmetric conjugated diynes can be obtained by several methods that include the different modifications of the Glaser-Eglinton-Hay oxidative coupling.

Herein we report the synthesis and NMR characterization of bis-4,4-(5-oxo-4,5-seco-3-yne-steroids) by coupling the corresponding 5-oxo-4,5-seco-3-yne steroid units. An X-ray diffraction analysis of compound $\mathbf{5 b}$ confirmed the proposed structure and provided detailed information about the bond lengths, bond angles and the conformation that the molecules adopt in the crystal state.

\section{Results and Discussion}

The starting alkynones $\mathbf{4 a , b}$ were obtained following our previously described sequences that include, as key steps, the epoxidation of $\alpha, \beta$-unsaturated ketones and the Eschenmoser-Tanabe fragmentation of a mixture of diastereomeric epoxides (Scheme 1). ${ }^{8,9,12}$

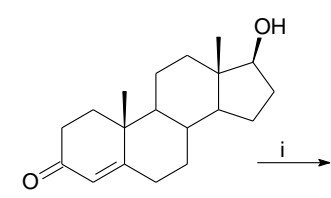

$1 \mathbf{a}$

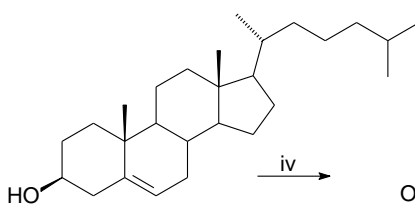

$1 b$

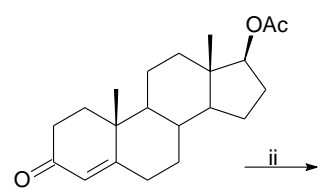

2a

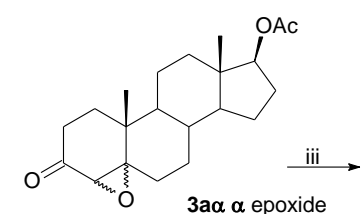

$3 a \beta \beta$ epoxide

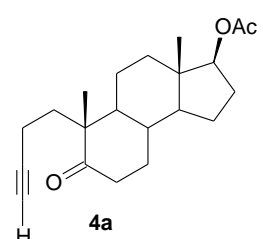

$4 a$

i) $\mathrm{Ac}_{2} \mathrm{O}$, pyr; ii) $\mathrm{H}_{2} \mathrm{O}_{2}, \mathrm{CH}_{2} \mathrm{Cl}_{2}, \mathrm{MeOH}$; iii) $\mathrm{NH}_{2}-\mathrm{NHT}, \mathrm{CH}_{2} \mathrm{Cl}_{2}, \mathrm{AcOH}$, iv) Oppenauer oxidation

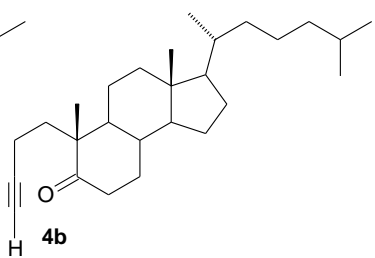

Scheme 1. Our previously reported synthesis of the 5-oxo-4,5-seco-3-yne steroids $\mathbf{4 a}$ and $\mathbf{4 b}$.8,9,12 
The first attempts at dimerization included the conditions of the Hay coupling ${ }^{13}$ that employs TMEDA as base and a catalytic amount of $\mathrm{CuCl}$ in acetone under an oxygen atmosphere. Although this procedure produced the desired dimerization, TLC analysis indicated that after 16 hours the amount of starting material was significant. The more drastic conditions of the Eglinton version ${ }^{14}$ in which the alkyne and an excess of cupric acetate are refluxed in methanolic pyridine produced the desired dimers in moderate yields after chromatographic purification (Scheme 2, and Table 1, Method A).

During the course of a parallel investigation ${ }^{9}$ we observed that Sonogashira coupling of the alkynone $4 a$ with o-iodobenzyl alcohol employing $\mathrm{Pd}\left(\mathrm{PPh}_{3}\right)_{4}$ and $\mathrm{Cul}$ in triethylamine produced a significant amount of the dimer $\mathbf{5} \mathbf{a}$ as side product. Exclusion of the oxygen by consecutive purging cycles with Ar under sonication solved this problem. This prompted us to drive the reaction to the desired dimers by removal of the iodinated derivative and saturation with oxygen. We were happy to find that treatment of the alkynones $4 \mathbf{a}, \mathbf{b}$ in such conditions afforded good yields of the desired dimers $\mathbf{5 a , b}$ in reactions with a clean, fast and easy work-up, followed by chromatographic purification (Scheme 2, and Table 1, Method B).
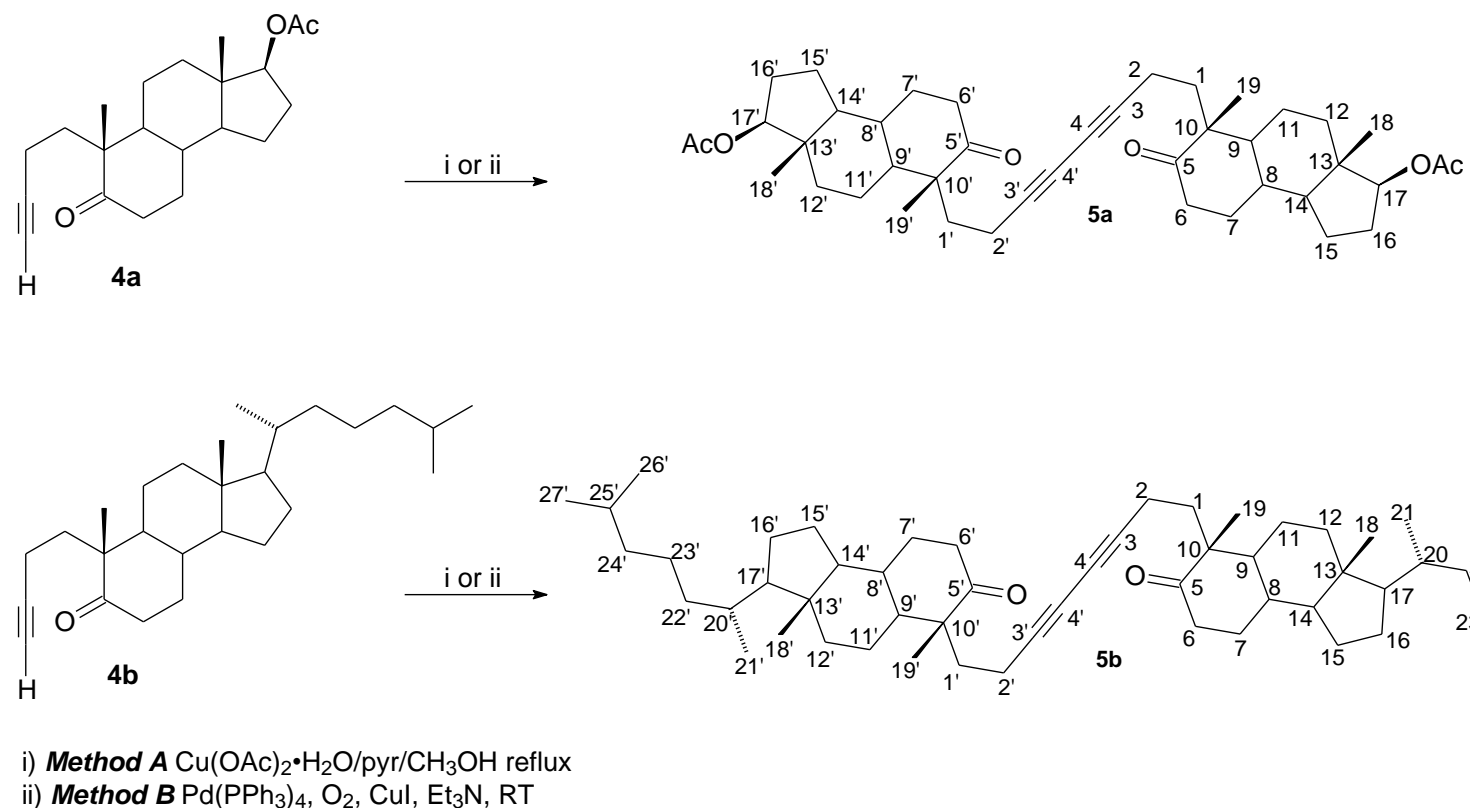

Scheme 2. Synthesis of dimeric steroids $\mathbf{5 a , b}$.

Table 1. Yields of the coupling reactions

\begin{tabular}{lcc}
\hline & $5 a$ & $5 b$ \\
\hline Method A (Eglinton) & $222 \mathrm{mg}, 67 \%$ & $259 \mathrm{mg}, 68 \%$ \\
Method B (Pd catalyzed) & $303 \mathrm{mg}, 92 \%$ & $312 \mathrm{mg}, 81 \%$ \\
\hline
\end{tabular}

NMR study allowed unambiguous characterization of the obtained compounds. With the exception of the ${ }^{13} \mathrm{C}$ signals of $\mathrm{C}-2, \mathrm{C}-3$ and $\mathrm{C}-4$, the dimerization does not induce significant changes in the NMR signals of the neighboring nuclei compared with those of the starting monomer 4 (See Tables 2 and 3). This suggests that in solution the dimeric compounds adopt a linear conformation in which each steroid core is placed well away from the other, resembling the conformation observed in solid state (vide infra). 
Table 2. Selected ${ }^{1}$ H NMR signals of the starting alkynones $\mathbf{4 a , b}$ and the obtained dimers $5 \mathbf{a}, \mathbf{b}^{*}(\delta, \mathrm{ppm})$

\begin{tabular}{cccccccc}
\hline & $\mathbf{4 a}^{\mathbf{1 2}}$ & $\mathbf{4 b}^{\mathbf{8}}$ & $\overline{\mathbf{X}}_{\mathbf{4}}$ & $\mathbf{5 a}$ & $\mathbf{5 b}$ & $\overline{\mathbf{X}}_{\mathbf{5}}$ & $\Delta \overline{\mathbf{X}}_{\mathbf{5}}-\overline{\mathbf{X}}_{\mathbf{4}}$ \\
\hline H-2 & 2.12 & 2.12 & 2.12 & 2.15 & 2.16 & 2.16 & +0.04 \\
H-4 & 1.92 & 1.92 & 1.92 & - & - & - & - \\
H-6 ax & 2.51 & 2.51 & 2.51 & 2.50 & 2.50 & 2.50 & -0.01 \\
H-6 eq. & 2.25 & 2.25 & 2.25 & 2.27 & 2.25 & 2.26 & +0.01 \\
H-19 & 1.08 & 1.08 & 1.08 & 1.07 & 1.07 & 1.07 & -0.01 \\
\hline
\end{tabular}

$\bar{X}=$ mean value, $*$ Since the dimers $\mathbf{5 a}, \mathbf{b}$ are $C_{2}$ symmetrical, the chemical shifts of protons are identical for both halves

Table 3. Selected ${ }^{13} \mathrm{C}$ NMR signals of the starting alkynones $4 \mathbf{a}, \mathbf{b}$ and the obtained dimers $5 \mathbf{a}, \mathbf{b} *(\delta, \mathrm{ppm})$

\begin{tabular}{cccccccc}
\hline & $\mathbf{4 a}^{\mathbf{1 2}}$ & $\mathbf{4 b}^{\mathbf{8}}$ & $\overline{\mathbf{X}} \mathbf{4}$ & $\mathbf{5 a}$ & $\mathbf{5 b}$ & $\overline{\mathbf{X}}_{\mathbf{5}}$ & $\Delta \overline{\mathbf{X}}_{\mathbf{5}} \overline{\mathbf{X}}_{\mathbf{4}}$ \\
\hline C-1 & 33.5 & 33.6 & 33.6 & 33.3 & 33.3 & 33.3 & -0.3 \\
C-2 & 13.7 & 13.7 & 13.7 & 14.5 & 14.6 & 14.6 & +0.9 \\
C-3 & 84.9 & 85.1 & 85.0 & 77.8 & 77.9 & 77.9 & -7.2 \\
C-4 & 68.1 & 67.9 & 68.0 & 65.3 & 65.3 & 65.3 & -2.7 \\
C-5 & 214.1 & 214.7 & 214.4 & 214.1 & 214.7 & 214.4 & 0.0 \\
C-6 & 37.9 & 38.2 & 38.1 & 37.9 & 38.2 & 38.1 & -0.1 \\
C-7 & 30.5 & 31.2 & 30.9 & 30.5 & 31.2 & 30.9 & 0.0 \\
C-8 & 34.6 & 34.8 & 34.7 & 34.6 & 34.9 & 34.8 & 0.0 \\
C-9 & 47.3 & 47.4 & 47.4 & 47.4 & 47.5 & 47.5 & +0.1 \\
C-10 & 50.7 & 50.7 & 50.7 & 50.7 & 50.7 & 50.7 & 0.0 \\
C-19 & 20.5 & 20.6 & 20.6 & 20.5 & 20.5 & 20.5 & -0.1 \\
\hline
\end{tabular}

$\overline{\mathrm{X}}=$ mean value, ${ }^{*}$ Since the dimers $\mathbf{5} \mathbf{a}, \mathbf{b}$ are $\mathrm{C}_{2}$ symmetrical, the chemical shifts of carbon atoms are identical for both halves

\section{Crystal structure discussion}

While all attempts at production of monocrystals of compounds 5 a suitable for X-ray diffraction were unsuccessful, crystallization of compound $\mathbf{5 b}$ from ethyl acetate-acetone afforded monocrystals suitable for such studies.

The molecular structure of 4,4'-bis(4,5-secocholest-3-yn-5,5'-dione) (5b) was solved in the monoclinic space group $C 2$ and $Z=2$. The asymmetric unit contains only half of the dimeric molecule and the other half is generated by a 2 -fold rotation axis perpendicular to the alkyne moiety which deviates slightly from linearity $\left(175.6^{\circ}\right)$, in accordance with similar steroidal dimeric structures ${ }^{15,16}$ as shown in Figure 1 . Additionally, the planes of both steroidal cores adopt an orthogonal position with respect to the dialkyne axis.

The dimeric molecules of compound $\mathbf{5 b}$ are packed in parallel layers propagated by $\mathrm{C}(2)-\mathrm{H}(2) \cdots \mathrm{O}_{\text {carbonyl }}$

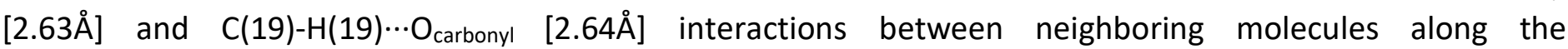
crystallographic bc plane. This particular arrangement favors the interaction between the hydrophobic faces of adjacent steroidal dimers generating a multidimensional highly crowded packed columnar self-assembly (see Figure 2).

The absolute configuration of compound $\mathbf{5 b}$ can be assumed without risk, as that known for the starting material considering that the synthetic transformations carried out do not affect the absolute configuration of 
the chiral centres in the naturally occurring steroid framework. Crystal data and experimental details of the structure determination of compound $\mathbf{5 b}$ are listed in Table $4 .{ }^{17}$
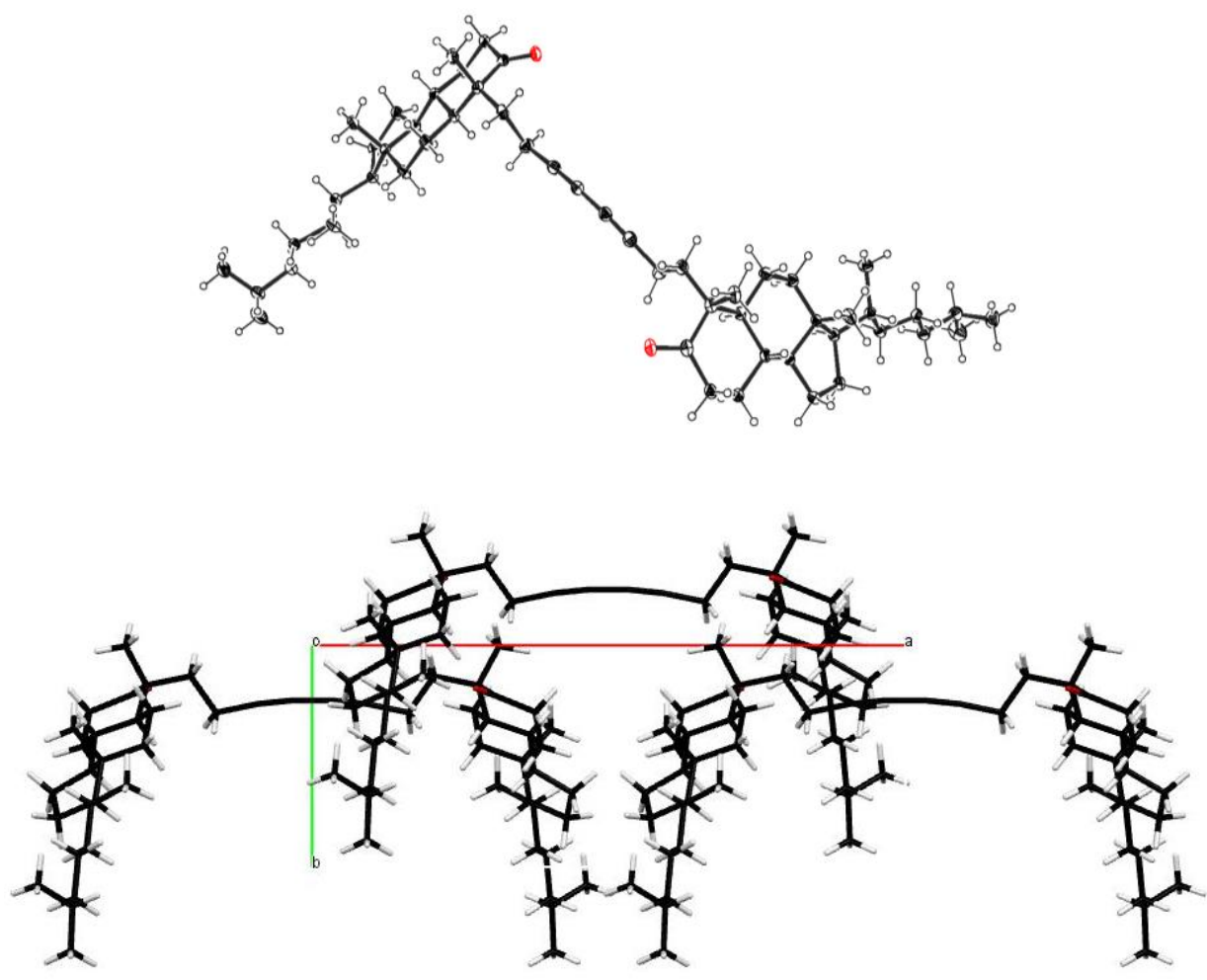

Figure 1. ORTEP perspective of compound $\mathbf{5 b}$ with thermal ellipsoids drawn at $50 \%$ probability level for all atoms other than hydrogen, with their corresponding unit cell viewed along the crystallographic $\mathrm{c}$ axis.
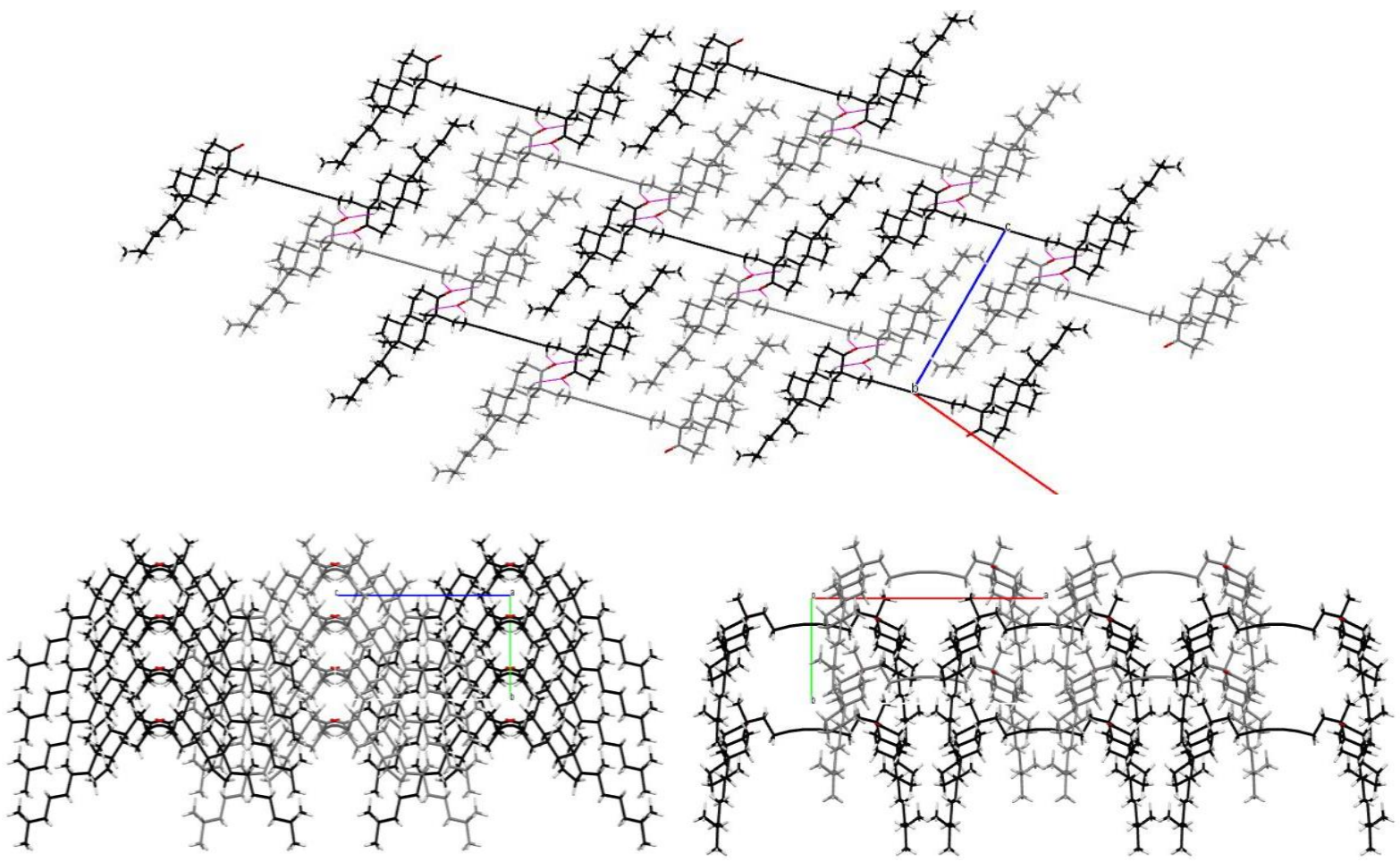

Figure 2. Crystal packing of compound $\mathbf{5 b}$. 
Table 4. Crystal data and structure refinement for the dimeric steroid $\mathbf{5 b}$

\begin{tabular}{|c|c|}
\hline Parameters & Value \\
\hline Empirical formula & $\mathrm{C}_{54} \mathrm{H}_{86} \mathrm{O}_{2}$ \\
\hline Formula weight & 767.22 \\
\hline Temperature & $130(2) \mathrm{K}$ \\
\hline Wavelength & $1.54184 \AA$ \\
\hline Crystal system & Monoclinic \\
\hline Space group & $\mathrm{C} 2$ \\
\hline Unit cell dimensions & $a=20.6034(19) \AA, b=7.4289(6) \AA, c=15.9737(14) \AA, \beta=101.557(9)^{\circ}$ \\
\hline Volume & $2395.4(4) \AA^{3}$ \\
\hline Z & 2 \\
\hline Density (calculated) & $1.064 \mathrm{Mg} / \mathrm{m}^{3}$ \\
\hline Absorption coefficient & $0.461 \mathrm{~mm}^{-1}$ \\
\hline$F(000)$ & 852 \\
\hline Crystal size & $0.410 \times 0.170 \times 0.030 \mathrm{~mm}^{3}$ \\
\hline Theta range for data collection & 4.381 to $74.132^{\circ}$ \\
\hline Index ranges & $-24<=\mathrm{h}<=25,-9<=\mathrm{k}<=5,-19<=\mathrm{k}<=19$ \\
\hline Reflections collected & 8086 \\
\hline Independent reflections & $3267[\mathrm{R}($ int $)=0.0566]$ \\
\hline Completeness to theta $=67.684^{\circ}$ & $100.0 \%$ \\
\hline Refinement method & Full-matrix least-squares on $\mathrm{F}^{2}$ \\
\hline Data / restraints / parameters & 3267 / 1 / 258 \\
\hline Goodness-of-fit on $\mathrm{F}^{2}$ & 1.066 \\
\hline Final $R$ indices [I>2sigma(I)] & $R 1=0.0505, w R 2=0.1202$ \\
\hline $\mathrm{R}$ indices (all data) & $R 1=0.0734, w R 2=0.1388$ \\
\hline Absolute structure parameter & $0.1(6)$ \\
\hline Extinction coefficient & $\mathrm{n} / \mathrm{a}$ \\
\hline Largest diff. peak and hole & 0.186 and -0.195 e. $\AA^{-3}$ \\
\hline
\end{tabular}

\section{Conclusions}

We have developed straightforward procedures that allow the synthesis of dimers constituted of two units of a 5-oxo-4,5-seco-3-yne steroid derived from the naturally occurring compounds testosterone (1a), and cholesterol (1) . Although both procedures afforded the desired compounds, the palladium-catalyzed homocoupling emerged as more convenient than the Eglinton procedure due to its more environmental friendly conditions, higher yields and easier work-up of the reaction mixture.

Crystallographic studies showed that the flexible diyne spacer of dimer $\mathbf{5 b}$ favors a crystal packing dominated by interactions that are capable of accommodationg the steroid cores in a highly crowded packed columnar self-assembly. Further studies to explore the solid-state properties and synthetic applications of dimers derived from the obtained compounds are in development. 


\section{Experimental Section}

General. Reactions were monitored by TLC on ALUGRAM SIL G/UV254 plates from MACHEREY-NAGEL. TLC plates were sprayed with a $1 \%$ solution of vanillin in $50 \% \mathrm{HClO}_{4}$ and heated until color developed. Melting points were measured on a Melt-Temp II apparatus. NMR spectra were recorded in $\mathrm{CDCl}_{3}$ solutions in a Varian INOVA 400 spectrometer using the solvent signal as reference. NMR signals assignments were carried out with the aid of combined 1D and 2D NMR techniques that included ${ }^{1} \mathrm{H},{ }^{13} \mathrm{C}$, COSY, Nuclear Overhauser Effect Spectroscopy (NOESY), Heteronuclear Single Quantum Correlation (HSQC) and Heteronuclear Multiple Bond Correlation (HMBC). High resolution mass spectra were registered in a Jeol, AccuTOF JMS-T100LC spectrometer. The starting alkynones $\mathbf{4 a}$ and $\mathbf{4 b}$ were obtained following our previously described protocols (vide supra Scheme 1). ${ }^{8,9,12}$ Previously obtained physical and NMR data for $\mathbf{4 a}$ and $\mathbf{4 b}$ are provided for comparison purposes.

$17 \beta$-Acetoxy-4,5-epoxy-5 $\beta$-androstan-3-one (4a). ${ }^{12} \mathrm{Mp} 140-142{ }^{\circ} \mathrm{C}$ (from EtOAC) $\left.{ }^{1} \mathrm{H} \mathrm{NMR} \mathrm{(400} \mathrm{MHz}^{\mathrm{CDCl}} \mathrm{CD}_{3}\right)$ S ppm: 4.59 (dd, J 9.2, 7.8 Hz, 1H, H-17), 2.51 (ddd, J 14.5, 6.3, 6.3 Hz, 1H, H-6 ax.), 2.26 (ddd, J 14.7, 4.5, 2.4 $\mathrm{Hz}, 1 \mathrm{H}, \mathrm{H}-6$ eq.), 1.91 (m, 1H, H-4), 2.03 (s, 3H, $\mathrm{CH}_{3}$ acetyl), 1.07 (s, 3H, H-19), 0.84 (s, 3H, H-18). ${ }^{13} \mathrm{C} \mathrm{NMR}$ $\left(\mathrm{CDCl}_{3} 100 \mathrm{MHz}\right) \delta$ ppm: 33.5 C-1, 13.7 C-2, 84.9 C-3, 68.1 C-4, 214.1 C-5, 37.9 C-6, 30.5 C-7, 34.6 C-8, 47.3 C-9, 50.7 C-10, 21.0 C-11, 36.2 C-12, 42.5 C-13, 50.2 C-14, 23.5 C-15, 27.4 C-16, 82.3 C-17, 12.0 C-18, 20.5 C-19, $21.1 \mathrm{CH}_{3}$ acetyl, $171.1 \mathrm{C}=\mathrm{O}$ acetyl.

4,5-secocholest-3-yn-5-one (4b). ${ }^{8}$ Transparent oil. ${ }^{1} \mathrm{H}$ NMR ( $\left.\mathrm{CDCl}_{3}, 400 \mathrm{MHz}\right): \delta$ ppm: 2.51 (td, J 14.5, 6.4 Hz, 1H, H-6 ax.), 2.25 (ddd, J 14.5, 4.5, $2.3 \mathrm{~Hz}, 1 \mathrm{H}, \mathrm{H}-6$ eq.), 1.92 (t, J $2.4 \mathrm{~Hz}, 1 \mathrm{H}, \mathrm{H}-4), 2.12$ (m, 2H, H-2) 1.08 (s, 3H, $\mathrm{H}-19), 0.91$ (d, J $6.5 \mathrm{~Hz}, 3 \mathrm{H}, \mathrm{H}-21), 0.87$ (d, J $1.8 \mathrm{~Hz}, 3 \mathrm{H}, \mathrm{H}-26), 0.85$ (d, J $1.8 \mathrm{~Hz}, 3 \mathrm{H}, \mathrm{H}-27), 0.72(\mathrm{~s}, 3 \mathrm{H}, \mathrm{H}-18) .{ }^{13} \mathrm{C}$ NMR $\left(\mathrm{CDCl}_{3}, 100 \mathrm{MHz}\right) \delta$ ppm: $33.6 \mathrm{C}-1,13.7 \mathrm{C}-2,85.1 \mathrm{C}-3,67.9 \mathrm{C}-4,214.7 \mathrm{C}-5,38.2 \mathrm{C}-6,31.2 \mathrm{C}-7,34.8 \mathrm{C}-8$, 47.4 C-9, 50.7 C-10, 21.5 C-11, 39.3 C-12, 42.5 C-13, 55.8 C-14, 23.8 C-15, 28.1 C-16, 56.0 C-17, 12.0 C-18, 20.6 C-19, 35.7 C-20, 18.6 C-21, 36.1 C-22, 24.2 C-23, 39.5 C-24, 28.0 C-25, 22.8 C-26, 22.5 C-27.

Method A (Eglinton coupling): A solution of the alkynone 4a, $4 \mathbf{b}(1 \mathrm{mmol})$ and $\mathrm{Cu}(\mathrm{OAc})_{2} \bullet \mathrm{H}_{2} \mathrm{O}(280 \mathrm{mg}, 1.40$ mmol) in $\mathrm{CH}_{3} \mathrm{OH} /$ pyridine $(10 \mathrm{~mL}, 1: 1)$ was refluxed for $6 \mathrm{~h}$. The mixture was cooled to $0{ }^{\circ} \mathrm{C}$ and poured carefully into chilled concentrated $\mathrm{HCl}(4 \mathrm{~mL})$ and extracted with EtOAc $(2 \times 30 \mathrm{~mL})$. The organic layer was washed with $\mathrm{H}_{2} \mathrm{O}(3 \times 20 \mathrm{~mL}), 10 \%$ aq. $\mathrm{CuSO}_{4}, \mathrm{H}_{2} \mathrm{O}(2 \times 30 \mathrm{~mL})$, dried $\left(\mathrm{Na}_{2} \mathrm{SO}_{4}\right)$ and evaporated to produce an oil that was purified in a column packed with silica gel (15 g) employing hexane-EtOAc 15/1 as eluent to afford the desired dimeric compound (See Table 1 for yields).

Method B (Pd catalyzed coupling): A mixture of the alkynone $(1 \mathrm{mmol}), \mathrm{Pd}\left(\mathrm{PPh}_{3}\right)_{4}(9.6 \mathrm{mg}, 0.0083 \mathrm{mmol})$ and Cul (3.2 mg, $0.0166 \mathrm{mmol}$ in $\mathrm{Et}_{3} \mathrm{~N}(3 \mathrm{~mL}$ ) was stirred at $\mathrm{rt}$ for $2 \mathrm{~h}$ under an oxygen atmosphere. EtOAc (50 mL) was added and the mixture was washed with $\mathrm{H}_{2} \mathrm{O}(5 \times 20 \mathrm{~mL})$ dried (anh. $\left.\mathrm{Na}_{2} \mathrm{SO}_{4}\right)$ and evaporated. The residue produced was purified in a chromatographic column packed with silica gel $(15 \mathrm{~g})$ that was eluted with hexane/EtOAc mixture $(10 / 0 \rightarrow 10 / 3)$ to afford the desired dimer (See Table 1 for yields).

4,4'-Bis-(4,5-secoandrost-3-yn-5-one) (5a). Oil. $\mathrm{NMR}^{1} \mathrm{H}\left(\mathrm{CDCl}_{3}, 400 \mathrm{MHz}\right) \delta$ (ppm): 4.59 (dd, J 9.2, 7.7 Hz, 2H, H-17ß, H-17ß'), 2.50 (ddd, J 15.0, 14.5, 6.3 Hz, 2H, H-6 ax. H-6'ax.), 2.27 (ddd, J 15.0, 4.6, 2.4 Hz, 1H, H-6 eq. H6'eq.), 2.15 (m, 4H, H-2 H-2'), 2.04 (s, 6H 2x CH 3 acetyl), 1.07 (s, 6H, H-19 H-19'), 0.84 (s, 6H, H-18 H-18') ${ }^{13} \mathrm{C}$ NMR $\left(\mathrm{CDCl}_{3}, 100.53 \mathrm{MHz}\right) \delta$ (ppm): 33.3 C-1 C-1', 14.5 C-2 C-2', 77.8 C-3 C-3', $65.3 \mathrm{C}-4 \mathrm{C}-44^{\prime}, 214.1 \mathrm{C}-5 \mathrm{C}-5^{\prime}, 37.9$ C-6 C-6', 30.5 C-7 C-7', 34.6 C-8 C-8', 47.4 C-9 C-9', 50.7 C-10 C-10', 21.1 C-11 C-11', 36.22 C-12 C-12', 42.5 C-13 C-13', 50.1 C-14 C-14', 23.5 C-15 C-15', 27.4 C-16 C-16', 82.4 C-17 C-17', 12.1 C-18 C-18', 20.5 C-19 C-19' 171.0 $2 \times \mathrm{C}=\mathrm{O}$ acetyl, $21.12 \times \mathrm{CH}_{3}$ acetyl. HRMS (FAB) Estimated for $\mathrm{C}_{42} \mathrm{H}_{59} \mathrm{O}_{6}\left(\mathrm{MH}^{+}\right)$659.4312, observed 659.4312. 
4,4'-Bis-(4,5-secocholest-3-yn-5-one) (5b). Mp. 132-135 ${ }^{\circ} \mathrm{C}$ (from EtOAc-Me $\left.{ }_{2} \mathrm{CO}\right) . \mathrm{NMR}^{1} \mathrm{H}\left(\mathrm{CDCl} \mathrm{B}_{3} 400 \mathrm{MHz}\right) \delta$ (ppm): 2.50 (td, J 14.4, 6.3 Hz, 2H, H-6 ax. H-6'ax.), 2.25 (m, 2H, H-6eq. H-6'eq.), 2.16 (m, 4H, H-2 H-2'), 1.07 (s, 6H, H-19 H-19'), 0.91 (d, J $\left.6.5 \mathrm{~Hz}, 6 \mathrm{H}, \mathrm{H}-21 \mathrm{H}-21^{\prime}\right), 0.87$ (d, J $\left.1.9 \mathrm{~Hz}, 6 \mathrm{H}, \mathrm{H}-26 \mathrm{H}-26^{\prime}\right), 0.85$ (d, J $1.9 \mathrm{~Hz}, 6 \mathrm{H}$, $\left.\mathrm{H}-27 \mathrm{H}-27^{\prime}\right), 0.72\left(\mathrm{~s}, 6 \mathrm{H}, \mathrm{H}-18 \mathrm{H}-18^{\prime}\right){ }^{13} \mathrm{C} \mathrm{NMR}\left(\mathrm{CDCl}_{3}, 100.53 \mathrm{MHz}\right) \delta(\mathrm{ppm}): 33.3 \mathrm{C}-1 \mathrm{C}^{\prime} 1^{\prime}, 14.6 \mathrm{C}-2 \mathrm{C}-2^{\prime}, 77.9 \mathrm{C}-$ 3 C-3', 65.3 C-4 C-4', 214.7 C-5 C-5', 38.2 C-6 C-6', 31.2 C-7 C-7', 34.9 C-8 C-8', 47.5 C-9 C-9', 50.7 C-10 C-10', 21.6 C-11 C-11', 39.3 C-12 C-12', 42.5 C-13 C-13', 56.1 C-14 C-14', 23.9 C-15 C-15', 28.1 C-16 C-16', 55.8 C-17 C-17', 12.0 C-18 C-18', 20.5 C-19 C-19', 35.7 C-20 C-20', 18.6 C-21 C-21', 36.1 C-22 C-22', 24.2 C-23 C-23', 39.5 C-24 C-24', 28.0 C-25 C-25', 22.6 C-26 C-26', 22.8 C-27 C-27'. HRMS Estimated for $\mathrm{C}_{54} \mathrm{H}_{87} \mathrm{O}_{2}\left(\mathrm{MH}^{+}\right)$767.6706, observed 767.6688 .

X-ray crystallography. A monocrystal of the dimer $\mathbf{5 b}$ grown by slow evaporation from an EtOAc-Me $\mathrm{CO}_{2}$ solution was mounted on a glass fiber in the goniometer head with a crystal-to-detector distance of $55.00 \mathrm{~mm}$ and crystallographic data were collected at $130 \mathrm{~K}$ with an Oxford Diffraction Gemini " $\mathrm{A}$ " diffractometer $\left(\lambda_{\text {cuk } \alpha}=\right.$ $1.54184 \AA$, monochromator: graphite) with a CCD area detector. The collected data set consisted of 19 runs of 1126 frames of intensity $\left(1^{\circ}\right.$ in $\left.\omega\right)$. The double pass method of scanning was used to exclude any noise. The collected frames were integrated by using an orientation matrix determined from the narrow frame scans. CrysAlisPro and CrysAlis RED software packages ${ }^{18}$ were used for data collection and integration. Analysis of the integrated data did not reveal any decay. Final cell parameters were determined by a global refinement of $1699\left(4.318<\theta<72.464^{\circ}\right)$. Collected data were corrected for absorption effects by analytical numeric absorption ${ }^{19}$ using a multifaceted crystal model based on expressions upon the Laue symmetry with equivalent reflections. Structure solution and refinement were carried with the programs SHELXS-2014 and SHELXL-2014 respectively. ${ }^{20}$ WinGX and ORTEP softwares ${ }^{21}$ were used to prepare material for publication. Fullmatrix least-squares refinement was carried out by minimizing $\left(\mathrm{Fo}^{2}-\mathrm{Fc}^{2}\right)^{2}$. All nonhydrogen atoms were anisotropically refined. Hydrogen atoms attached to carbons were placed in geometrically idealized positions and refined as riding on their parent atoms, with $\mathrm{C}-\mathrm{H}=0.98-1.00 \AA$ with Uiso $(\mathrm{H})=1.2 \mathrm{Ueq}(\mathrm{C})$ for methylene and methyne groups, and Uiso $(H)=1.5$ Ueq $(C)$ for methyl groups.

\section{Acknowledgements}

The authors acknowledge the financial support provided by Dirección General de Asuntos del Personal Académico (Project DGAPA-IN211714) and the Faculty of Chemistry (PAIP-5000-9063). Thanks are due to CONACYT-Mexico for the scholarship granted to C.A.-M. and to DGAPA-ICN for a postdoctoral fellowship granted to R.A.-R. We want to express our gratitude to Rosa I. del Villar Morales (USAI-UNAM) for recording NMR spectra and to Dr. Carlos Cobas from Mestrelab for assistance with the MestreNova NMR processing program. We thank Professor John Boulton for correcting the manuscript.

\section{Supplementary Material}

${ }^{1} \mathrm{H}$ and ${ }^{13} \mathrm{C}$ NMR spectra of the dimeric steroids $\mathbf{5 a}$ and $\mathbf{5 b}$. 


\section{References}

1. Banerji, J.; Chatterjee, A. Indian. J. Chem. 1973, 11, 1056.

2. Mosettig, E.; Scheer, I. J. Org. Chem. 1952, 17, 764. https://doi.org/10.1021/jo01139a016

3. D’Auria, M. V.; Giannini, C.; Zampella, A.; Minale, L.; Debitus, C.; Roussakis, C.; Crellastatin, A. J. Org. Chem. 1998, 63, 7382.

https://doi.org/10.1021/jo981022v

4. Iglesias-Arteaga, M. A.; Morzycki, J. W. The alkaloids: chemistry and biology. 2014, 72, 153. https://doi.org/10.1016/B978-0-12-407774-4.00002-9

5. Li, Y. X.; Dias, J. R. Chem Rev. 1997, 97, 283. https://doi.org/10.1021/cr9600565

6. Nahar, L.; Sarker, S. D.; Turner, A. B. Curr. Med. Chem. 2007, 14, 1349. https://doi.org/10.2174/092986707780597880

7. Nahar, L.; Sarker, S. D. Steroid Dimers. Chemistry and applications in drug design and delivery, $1^{\text {st }}$ Edn; John Wiley \& Sons Ltd: United Kingdom, 2012. https://doi.org/10.1002/9781119970934.ch6

8. Alarcón-Manjarrez, C.; Arcos-Ramos, R.; Flores-Álamo, M.; Iglesias Arteaga. M. A. Steroids 2016, $109,66$. https://doi.org/10.1016/i.steroids.2016.03.001

9. Mayorquin-Torres, M. C.; Flores-Alamo, M.; Iglesias-Arteaga, M. A. Tetrahedron Lett. 2017, $58,2073$. https://doi.org/10.1016/j.tetlet.2017.04.051

10. Stefani, H. A.; Guarezemini, A. S.; Cella, R. Tetrahedron 2010, 66, 7871. https://doi.org/10.1016/j.tet.2010.07.001

11. Shi, W.; Lei, A. Tetrahedron Lett. 2014, 55, 2763. https://doi.org/10.1016/j.tetlet.2014.03.022

12. Labra-Vázquez, P.; Romero-Ávila, M.; Flores-Álamo, M.; Iglesias-Arteaga M. A. J. Chem. Crystallogr. 2013, 43, 605. https://doi.org/10.1007/s10870-013-0466-2

13. Hay, A. S. J. Org. Chem. 1962, 27, 3320. https://doi.org/10.1021/jo01056a511

14. Müller, T.; Hulliguer J.; Seichter, W.; Weber, E.; Weber, T.; Wübbenhorst, M. Chem. Eur. J. 2000, 6, 54. https://doi.org/10.1002/(SICI)1521-3765(20000103)6:1<54::AID-CHEM54>3.0.CO;2-Y

15. Rodríguez-Molina B.; Ochoa M. E.; Romero, M.; Khan, S. I.; Farfán, N.; Santillan, R.; Garcia-Garibay, M. A. Cryst. Growth Des. 2013, 13, 5107. https://doi.org/10.1021/cg4012873

16. Khripack, V. A.; Zhabinskii, V. N.; Konstantinova, O. V.; Tsavlovskii, D. V.; Baranovsky, A. V.; Lyakhov, A. S.; Drasar, P. J. Mol. Struct. 2013, 1032, 1. https://doi.org/10.1016/i.molstruc.2012.07.001

17. Crystallographic data have been deposited with the Cambridge Crystallographic Data Centre as supplementary publication CCDC 1450338. Copies of the data can be obtained free of charge on application to CCDC, 12 Union Road, Cambridge, CB2 1EZ, UK (fax: (+44) 1223-336-033, e-mail: deposit@ccdc.cam.ac.uk).

18. CrysAlis PRO and CrysAlis RED. Agilent Technologies 2013, Yarnton, England. 
19. Clark, R. C.; Reid, J. S. Acta Crystallogr. 1995 A51, 887. https://doi.org/10.1107/S0108767395007367

20. Sheldrick, G. M. Acta Crystallogr. A 2008; A64, 112. https://doi.org/10.1107/S0108767307043930

21. Farrugia, L. J. J. Appl. Crystallogr. 2012, 45, 849. https://doi.org/10.1107/S0021889812029111 